\title{
DETERMINANTS OF THE USE OF SUBSIDIES FOR THE DEVELOPMENT OF RURAL AREAS BY SMALL AGRICULTURAL HOLDINGS: CASE OF POLAND
}

\author{
Barbara Wieliczko ${ }^{1}$, assistant professor; Agnieszka Sompolska-Rzechuła², assistant \\ professor and Agnieszka Kurdyś-Kujawska ${ }^{3}$, assistant professor \\ ${ }^{1}$ Institute of Agricultural and Food Economics -National Research Institute, Warsaw, Poland; ${ }^{2}$ West Pomerania \\ University of Technology Szczecin, Faculty of Economics, Department of Applied Mathematics in Economics; \\ ${ }^{3}$ Koszalin University of Technology, Faculty of Economics, Department of Finance
}

\begin{abstract}
The study analysed factors influencing farmers' decisions on the use of subsidies for rural development in small farms in Poland. The study included technical, economic and social features of 1,485 farms with an area of up to 10 ha of UAA participating in the FADN system in 2016. Applying an econometric probit model, variables were identified that should be taken into account when developing rural development policy aimed at increasing the likelihood of using subsidies in farms and thus fostering the achievement of the CAP objectives. The study showed that four variables were significant of eleven analysed. They presented a good fit into the model, as evidenced by the used measures for assessing the quality of the model (coefficient $R_{\text {calc }}^{2}$ and ROC curve). It was found that the decision to use subsidies for rural development in small farms in Poland depends on the farmer's level of education, the quality of the land, the area of arable land and the efficiency of agricultural activity. The chance of using subsidies unrelated to production in small farms grows with increasing area of arable land. On the other hand, the chance of using subsidies for rural development decreases with the increase in the farmer's level of education, better soil quality and increased agricultural productivity. The presented research shows that the characteristics of farmers (education), technical characteristics of farms (soil quality, agricultural area) and the agricultural system (agricultural productivity) are important aspects that should be taken into account in the creation of a new conceptual framework for rural development policy to intensify use of subsidies by farmers from small farms. A comprehensive approach to agricultural development programs, including a whole range of factors that influence farmers' decisions on the use of subsidies for rural development will bring tangible results in the form of significant and sustainable development.
\end{abstract}

Key words: subsidies, rural development, small farms, logit model.

JEL code: Q18, Q12, R58.

\section{Introduction}

Small farms, as the history of economic development indicates, even in a highly technically developed agriculture remain a key player in food production and job creation in rural areas (Czyzewski A., Stepien S., 2013). They also play an important role in the delivery of public goods, social services and environmental services, while contributing to soil conservation, watershed services, biodiversity, and carbon sequestration, as well as poverty reduction and food security (FAO, 2004). Small farms are an important element of European rural areas. However, without a properly targeted agricultural policy and an active promotion the development of small farms, it will be difficult for them to survive in the current reality. The recent debates on the shape of the CAP after 2020 clearly indicate that this policy should be more flexible. Member States are to be given more discretion as to how distribute their allocations under the CAP. This will allow them to develop customized programs responding to the problems of farmers and wider rural communities in the most effective way (European Commision, 2017). Most small farms without public support have No chance of surviving on an increasingly demanding and competitive market. To increase their income, they must either go to high-value agricultural production or increase the share of income from non-agricultural sources (Gulati A., Delgado M. N. C., Bora S., 2005). This is possible, inter alia, thanks to the support of agriculture under the second pillar of the CAP. Farmers have the option of

\footnotetext{
${ }^{1}$ e-mail: barbara.wieliczko@ierigz.waw.pl

2 e-mail: asompolska@zut.edu.pl

3 e-mail: agnieszka.kurdys-kujawska@tu.koszalin.pl
} 
applying for non-production subsidies targeted at supporting rural development. These subsidies include, among others, agri-environmental subsidies, subsidies for areas with unfavourable conditions for agricultural production, agricultural advisory services, subsidies to improve the quality of agricultural products, training, afforestation and maintaining the ecological balance of the forest environment. So far, a number of studies have been carried out relating to the issue of subsidies in agriculture. The research issues addressed included allocation of subsidies in agriculture, impact of subsidies on production and economic results of agricultural holdings, environment, rural community, development of rural areas, as well as identification of factors determining their use (Lakner $\mathrm{S}$., 2009; Fan B., 2011; Rizov M. et al., 2013; Mary S., 2013; Kazukauskas A., Newman C., Sauer J., 2014; Li J., Xu Y., 2015; Cimpoies L., 2015; Pechrova M., 2015; Balezentis T., De Witte K., 2015; Sun W., Zhai Y, 2016; Ferto I., Zoltana B., Varga A., 2016; Kravcakova V., Kotulic, 2016; Capitanio F. et al., 2016; Soliwoda M., 2017; Wieliczko B., Kurdys-Kujawska A., Herda-Kopanska J., 2017; Wieliczko B., Kurdys-Kujawska A., Sompolska-Rzechula A., 2018; Kurdys-Kujawska A., Sompolska-Rzechula A., 2018; Li J., 2018; Lemanowicz M., 2018; Lakner S., 2018). It seems, however, that the problem of factors determining farmers' decisions on the use of subsidies not related to production has not yet been sufficiently examined. There are many programs in Poland supporting small farms. The question of who benefits from them is worth answering. A better understanding of the factors that determine farmers' decisions regarding the use of non-production subsidies is key to creating effective farmer support programs. Considering the importance of this topic, the main goal of this research study is to identify and assess factors affecting farmers' decisions on the use of subsidies for rural development in small farms in Poland.

\section{Material and methods}

The study used farm data that was available in the Polish Farm Accountancy Data Network (FADN). For the research, 1485 farms classified as very small and small were selected. These are entities in which the area of agricultural land amounts to No more than 10 ha. The owners of farms mostly had basic vocational education in agriculture (38.31\%). At the same time, every fifth farmer had basic vocational non-agricultural education, non-agricultural secondary education or agricultural secondary education. Only $4.71 \%$ of farmers in the sample had basic education. Persons managing small farms were on average 49 years old. The average area of land used was 6.69 ha. In more than half of small farms, agricultural income was equal to or exceeded PLN 15,462 (app. EUR 3.600). A significant part of farms $(97.71 \%)$ demonstrated the ability to self-finance their activities and create savings as part of operating activities. To a lesser extent, the surveyed entities used loans or borrowings $(15.21 \%)$. In $27.28 \%$ of the surveyed farms, No investments were made. On the other hand, in $34.41 \%$ of farms the value of sold fixed assets was higher than the value of purchased and produced fixed assets. Non-productive subsidies received $53.73 \%$ of the farms covered by the study. In more than half of them, the amount of subsidies received was above PLN 1,534 (app. EUR 360). The value of received subsidies showed very large variation (coefficient of variation of $254 \%$ ). The minimum amount of subsidies was PLN 188 (app. EUR 45), while the maximum amount was PLN 100,000 (app. EUR 23.300). To estimate the likelihood of small farmers benefiting from subsidies for rural development, logistic regression was applied. In linear regression models, a linear relationship is assumed between the explained variable $(Y)$ and the explanatory variable $(X)$. The

${ }^{1}$ A detailed description of logit modelling along with the assessment of its quality can e.g. in Kurdyś-Kujawska A., Sompolska-Rzechuła A. (2018), Determinants of Farmers Demand for Subsidized Agricultural Insurance in Poland, Proceedings of the 2018 International Conference "Economic Science for Rural Development 2018", No 47, Jelgava, LLU ESAF, pp. 164-173 DOI 10.22616/ESRD.2018.019. 
dependent variable is of a continuous type. However, in the case of logistic regression, it is assumed that the dependent variable is dichotomous or binary, i.e. $Y_{i}=0$ or 1 for all $i=1, \ldots, \mathrm{n}$. The regression model using the logistic function has the form:

$$
p_{i}=\frac{\exp \left(\beta_{0}+\beta_{1} X_{i}\right)}{1+\exp \left(\beta_{0}+\beta_{1} X_{i}\right)}
$$

where: $\beta_{0} i \beta_{1}$ are model parameters, $X_{i}$ independent variables that can be both qualitative and quantitative, $p_{i}$ is the probability that $Y_{i}=\mathbf{1}$. After linearization of equation (1), we obtain (Fratczak E., 2018):

$$
\frac{p_{i}}{1-p_{i}}=\exp \left(\beta_{0}+\beta_{1} X_{i}\right)
$$

In this case $\frac{p_{i}}{1-p_{i}}$ is called odds, and the log odds function
\[ p_{i}^{\prime}=\ln \left(\frac{p_{i}}{1-p_{i}}\right)=\beta_{0}+\beta_{1} X_{i} \]

Odds are defined as the ratio of the likelihood of occurring of an event and the probability of an event not occurring. Due to the fact that the logistic function is nonlinear, the direction coefficient $\beta_{i}$ represents the change in logic caused by the change of $X$ by one unit. In the context of odds, the interpretation of the directional coefficient is as follows: for $X$ variable having a continuous value exp $\left(\beta_{i}\right)$ is an increase in odds $Y=1$ for each unit of growth of $X$ variable; for $X$ variable having the dichotomic value $\exp \left(\beta_{i}\right)$ is an increase in the odds that $Y=1$, when $X=1$ in relation to the situation when $X=0$.

For the study selected were variables, which may influence farmers' decisions to use subsidies for rural development. The model uses a set of explanatory variables and the dependent variable is the receipt of subsidies for rural development $\left(Y\right.$ ). Explanatory variables are: $X_{1}$ - farmer's level of education (1- elementary, 2 - non-agricultural basic vocational, 3 - agricultural basic vocational, 4 non-agricultural secondary, 5 - agricultural secondary, 6 - non-agricultural tertiary, 7 - agricultural tertiary); $X_{2}$ - the age of the farmer (in years); $X_{3}$ - own work inputs (FWU); $X_{4}$ - soil quality index; $X_{5}$ - area of agricultural land (ha); $X_{6}$ - income from agricultural activity (PLN); $X_{7}$ - the ability to self-finance activities and create savings as part of operating activities (yes $-1 ;$ No -0 ); $X_{\mathbf{8}}$ - total liabilities (yes - $1 ; 0-$ no); $X_{9}$ - profitability of production (\%); $X_{10}$ - gross investment value $(\mathrm{PLN}) ; X_{11}-$ gross value added (PLN).

\section{Empirical results}

The analysis of the results of the estimation of the model parameters of the probability of using subsidies for rural development by small farms in Poland showed a statistical significance of four variables: $X_{1}$ - the level of education of the farmer; $X_{4}$ - soil quality index; $X_{5}$ - area of agricultural land (ha); $X_{11}$ - gross value added (PLN). The empirical results obtained from the estimation of the logit model are presented in Table 1. 
Evaluation of logit model parameters

\begin{tabular}{|l|l|c|c|c|}
\hline \multirow{2}{*}{ Variable } & \multicolumn{1}{|c|}{ Variable } & Parameter valuation & p-value & Odds ratio \\
\cline { 2 - 5 } & constant & 2.053012 & - & - \\
\hline$X_{\mathbf{1}}$ & Farmer's education level & -0.084644 & 0.036818 & 0.9188 \\
\hline$X_{\mathbf{4}}$ & Soil quality index & -3.620743 & 0.000001 & 0.0268 \\
\hline$X_{\mathbf{5}}$ & UAA & 0.22309 & 0.000001 & 1.2499 \\
\hline$X_{11}$ & Gross value added & -0.00002 & 0.002039 & 0.9999 \\
\hline
\end{tabular}
Source: authors' calculations

Table 2 present the accuracy of farm classification based on the elaborated model.

Accuracy of the logit model classification

\begin{tabular}{|c|c|c|c|}
\hline \multirow{2}{*}{$\begin{array}{c}\text { Classification of holdings based on the } \\
\text { logit model }\end{array}$} & \multicolumn{2}{|c|}{ Actual classification of the farm } & \multirow{2}{*}{$\begin{array}{l}\text { Overall accuracy of } \\
\text { the classification }\end{array}$} \\
\hline & $y_{i}=1$ & $y_{i}=0$ & \\
\hline$\hat{y}_{i}=1$ & 627 & 204 & \multirow{3}{*}{$74.47 \%$} \\
\hline$\hat{y}_{i}=0$ & 171 & 483 & \\
\hline Sensitivity, specificity & $78.75 \%$ & $70.31 \%$ & \\
\hline
\end{tabular}
Source: authors' calculations

The assessment of the quality of the model was based on the value of the coefficient $R_{\text {calc }}^{2}$ (74.47\%) and the ROC curve (Figure 1). The results indicate that the classification based on the model is much better than random. The results of the Hosmer-Lemenshowa test indicate that there are No significant differences between the empirical and theoretical numbers that result from the estimated logistic regression models. The model has a high ability to detect objects that do not have a given feature, i.e. the use of subsidies for rural development, as evidenced by high sensitivity values $(78.75 \%)$ and model specificity $(70.31 \%)$.

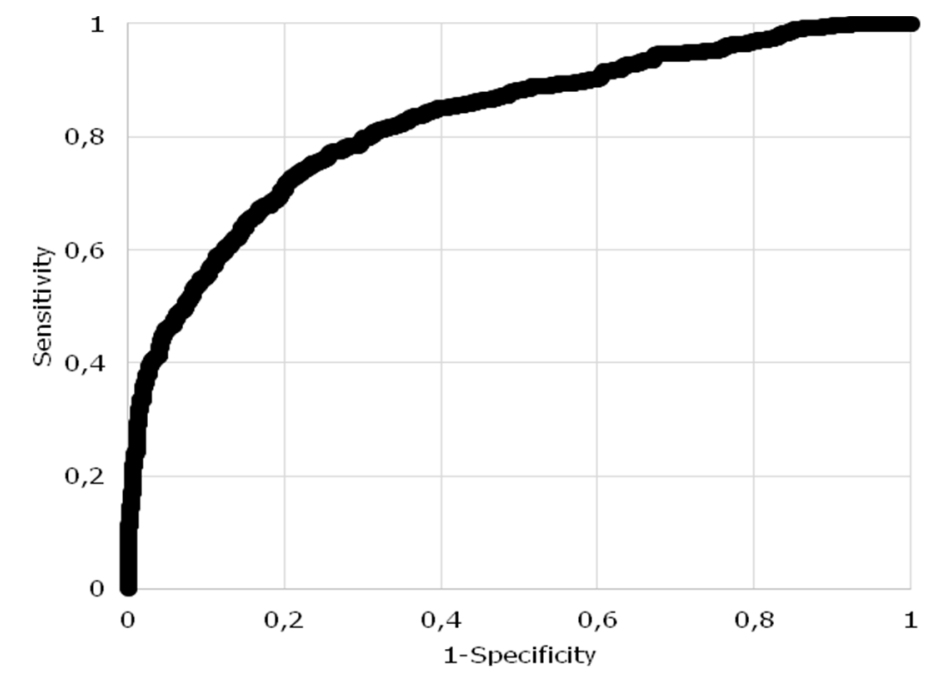

Source: oauthors' calculations

Fig. 1. The ROC curve for model

The area under the ROC curve equals 0.82 and is significantly larger than 0.5 (at a significance level greater than 0.000001).

In the model, the negative, statistically significant impact on the dependent variable is exercised by: farmer's level of education, soil quality index and gross value added. This means that the higher the farmers' level of education, the higher the soil quality index and the higher the gross value added, the less likely they are to use subsidies for rural development by small farms in Poland. However, 
the area of agricultural land has a positive, statistically significant impact on the dependent variable. This means that the larger the area of agricultural land, the higher the probability of using subsidies not related to production.

\section{Discussion}

The research results bring new insights into the considerations concerning the identification of factors affecting the probability of using subsidies directed to rural development unrelated to production by small farms in Poland.

Assuming the invariability of the other factors included in the model, first in relation to the farmer's education, the results indicate that the level of education determines decisions related to making use of subsidies by small farms. With the increase of the farmer's level of education by one category, the chance of benefiting from subsidies for rural development decreases by $8.11 \%$. Better educated farmers with higher qualifications are more likely to look for better paid work outside agriculture. The possibility of shifting labour resources and off-farm employment make them less interested in undertaking activities for the development of a farm. On the other hand, farmers with lower education, without appropriate qualifications, training and skills may have difficulties in seeking work outside agriculture. The possibility of using these subsidies allows them to adapt the farm to changing market demands, improve the quality of agricultural products, or, as in the case of LFA subsidies, compensate for lower incomes. Thus, subsidies may weaken non-agricultural activity of small farm owners.

Secondly, small farms with higher soil valuation rates are less likely to benefit from nonproduction subsidies. An increase in the soil quality index by one unit means that the chance of using these subsidies by small farms is down by $97.32 \%$. Higher production value of soil encourages small farm owners to make full use of its natural resources, which contributes to increasing agricultural income. In addition, these results confirm that subsidies for the development of rural areas, in particular subsidies for farms located in less favoured areas are an important tool for compensating for the losses in agricultural incomes and may also condition their further functioning.

Thirdly, the efficiency of agricultural activity is also an important determinant of subsidizing the development of small farms. At the same time, as the results indicate, the chance to use nonproduction subsidies will remain almost unchanged, with the increase of gross value added by PLN 1,000 . This means that irrespective of economic performance, which is a reflection of production efficiency, small farms are willing to use subsidies to improve the overall performance of the farm, including the increase in agricultural productivity.

Fourthly, the increase in the area of agricultural land by 1 ha enhances by $25 \%$ the chances of using subsidies unrelated to production. The lack of suitable land acreage may force farmers to undertake work outside of the farm. The area owned is mainly used for cultivation only for the needs of the farmer's household. This may suggest a lower inclination of farmers from farms with a smaller area to undertake activities for the development of their farm.

\section{Conclusions}

The study presents the results of a research on the identification and assessment of factors affecting farmers' decisions on the use of subsidies for rural development in small farms in Poland. Based on literature studies and the availability of data, explanatory variables were selected. The study included eleven variables related to technical, economic and social characteristics of small farms. Based on the conducted research, it can be concluded that the level of farmer's education, 
soil quality and gross value added reflected in the effectiveness of agricultural farms have a significant negative impact on the use of non-production subsidies by small farm owners. The chance of using subsidies unrelated to production by small farms in Poland decreases by $8.11 \%$ with an increase of the farmer's level of education by one category, and will decrease by $97.32 \%$ with a growth in the soil quality index by one. On the other hand, it remains almost unchanged, with the increase of gross value added by PLN 1,000. In turn, the area of agricultural land has a significant positive impact is the use of subsidies in small farms. Increasing the area of agricultural land by 1 ha raises by $25 \%$ the chance of using non-production subsidies.

The obtained results have a cognitive and an application-oriented character. They help to enhance the knowledge of the factors determining the decisions of small farms on the use of non-production subsidies. They can be a contribution to further research on subsidizing agriculture and they can also be used by public institutions responsible for promoting and formulating rural development policy.

\section{Bibliography}

1. Balezentis, T., De Witte, K. (2015). One-and-multi Directional Conditional Efficiency Measurement-Efficiency in Lithuanian Family Farms, European Journal of Operational Research, 245.

2. Capitanio, F., Gatto, E., Millemaci, E. (2016). CAP Payments and Spatial Diversity in Cereal Crops: An Analysis of Italian Farms, Land Use Policy 54.

3. Cimpoies, L. (2015). Subsidies and their Impact on the Competitiveness of the Agricultural Sector in Moldova. Proceedings of the $7^{\text {th }}$ International Scientific Conference Rural Development 2015.

4. Czyżewski, A., Stępień, S. (2013). Ekonomiczno-społeczne uwarunkowania zmian paradygmatu rozwoju rolnictwa drobnotowarowego w świetle ewolucji Wspólnej Polityki Rolnej (Economic and Social Conditions of Changes in the Paradigm of Small-scale agriculture development in the light of the evolution of the Common Agricultural Policy). Problemy Drobnych Gospodarstw Rolnych, No 2.

5. European Commision 2017. Retrieved: http://www.europarl.europa.eu. Access: 7.02.2019.

6. Fan, B. (2015). Effect Evaluation and Improvement Measures of the Subsidy Policy of Financial Benefit. Farmers Finance Research, 4.

7. FAO (2004). Socio-economic Analysis and Policy Implications of the Roles of Agriculture in Developing Countries. FAO Research Programme Summary Report. Rome: FAO.

8. Ferto, I., Zoltan, B., Varga, A. (2016). Impact of EU Subsidies on the Rural Areas in Hungary. Paper prepared for presentation at the $160^{\text {th }}$ EAAE Seminar 'Rural Jobs and the CAP', Warsaw, Poland.

9. Frątczak, E. (2018). Regresja logistyczna jako narzędzie modelowania poziomu i jakości życia (Logistic Regression as a Tool for Modeling the Level and Quality of Life). [in.] Jakość życia. Konsumpcja. Oficyna wydawnicza SGH, Warszawa.

10. Gulati, A., Delgado, M.N.C., Bora, S. (2005). Growth in High-value Agriculture in Asia and the Emergence of Vertical Links with Farmers. Linking Small-scale Producers to Markets: Old and New Challenges. Washington D.C.: The World Bank.

11. Kazukauskas, A., Newman, C., Sauer, J. (2014). The Impact of Decoupled Subsidies on Productivity in Agriculture: a Cross-country Analysis Using Microdata. Agricultural Economics, 45, 3.

12. Kravcakova, Vozarova, I., Kotulic R. (2016). Quantification of the Effect of Subsidies on the Production Performance of the Slovak Agriculture. Economics and Finance, 39.

13. Kurdyś-Kujawska, A., Sompolska-Rzechuła, A. (2018). Determinants of Farmers' Demand for Subsidized Agricultural Insurance in Poland. Proceedings of the 2018 International Conference "Economic Science for Rural Development", No 47 Jelgava. DOI 10.22616/ESRD.2018.019

14. Kurdyś-Kujawska, A., Sompolska-Rzechuła, A., Wsparcie publiczne rolnictwa krajów UE w ramach WPR. Skala, dynamika i tendencje zmian (Public Support for Agriculture of EU Countries under the CAP. Scale, Dynamics and Trends of Changes). [in:] Soliwoda M. (ed.), Subsydia a ekonomika, finanse i dochody gospodarstw rolniczych (4), Monografie Programu Wieloletniego 2015-2019, No. 77, Instytut Ekonomiki Rolnictwa i Gospodarki Żywnościowej - Państwowy Instytut Badawczy, Warszawa 2018.

15. Lakner, S., Kirchweger, S., Hoop, D., Brümmer, B., Kantelhardt, J. (2018). The Effects of Diversification Activities on the Technical Efficiency of Organic Farms in Switzerland, Austria, and Southern Germany. Sustainability 10, 1304.

16. Lakner, S. (2009). Technical Efficiency of Organic Milk-farms in Germany - the Role of Subsidies and of Regional Factors, Contributed Paper prepared for presentation at the International Association of Agricultural Economists Conference, Beijing, China, August 16-22.

17. Lemanowicz, M. (2018). Rural Development Programme as an Instrument of Financial Support for Agricultural Producer Groups in Poland. Proceedings of the 2018 International Conference "Economic Science for Rural Development", No. 49 Jelgava. DOI 10.22616/ESRD.2018.12 
18. Li, J. (2018). Agricultural Subsidies and Rural Family Entrepreneurship - Empirical Analysis Based on Chinese Microdata. American Journal of Industrial and Business Management, 8.

19. Li, J., Xu, Y. (2015). To Explore the Efficiency Loss of Agricultural Subsidy Policy from the Perspective of Farmers' Income. Statistical Study, 32.

20.Pechrova, M. (2015). The Effect of Subsidies on the Efficiency of Farms in the Liberecky Region. Economic revue - Central European Review of Economic, 18.

21. Rizov,M., Pokrivcak, J., Ciaian, P. (2013). CAP Subsidies and Productivity of the EU Farms. Journal of Agricultural Economics 64(3).

22. Mary, S. (2013). Assessing the Impacts of Pillar 1 and 2 Subsidies on TFP in French Crop Farms. Journal of Agricultural Economics, 64(1).

23. Soliwoda, M. (2017). Are Investment Subsidies for Farms still Unexplored? A Systematic Review. Agrarian Perspectives XXVI. Competitiveness of European Agriculture and Food Sectors. Proceedings of the 26th International Conference, 13-15 September 2017 Prague, Czech Republic.

24.Sun, W., Zhai, Y. (2016). The Influence of Agricultural Subsidy Policy on Farmer's Agricultural Production and Operation Intention. Take Liaoning Province as an Example. The Agricultural Economy, 12.

25. Wieliczko, B., Kurdyś-Kujawska, A., Herda-Kopańska, J. (2017). Mechanisms and Impulses Influencing Development of Agriculture and Rural Areas (3). Monographs of Multi-annual Programme 2015-2019, No. 58.1, IAFE-NRI, Warsaw 2017.

26. Wieliczko, B., Kurdyś-Kujawska, A., Sompolska-Rzechuła, A. (2018). Economic component of ANC Payments, Example of the Farms in Poland. Proceeding of Annual $24^{\text {th }}$ International Scientific Conference „Research for Rural Development 2018”, 2, Jelgava. 